\title{
Changes in regional ventilation and perfusion of the lung after endoscopic laser treatment
}

\author{
P J M George, G Clarke, S Tolfree, C P O Garrett, M R Hetzel
}

\begin{abstract}
To determine whether endoscopic laser treatment improves both ventilation and perfusion in patients with advanced lung cancer, krypton-81m ventilation and technetium-99m labelled macroaggregate perfusion scanning was performed immediately before and two or four days after treatment in a consecutive series of 28 patients. Twelve patients had not received any other treatment before laser therapy and 16 had undergone previous treatments that included radiotherapy. Ventilation and perfusion were quantified by expressing the number of counts in the affected lung as a percentage of the total counts. Ventilation and perfusion improved after laser treatment in 23 patients (82\%). The mean ventilation score in the affected lung rose by $50 \%(p<0.001)$ and the mean perfusion score rose by $24 \%$ ( $p<$ $0.001)$. Incremental changes in ventilation and perfusion scores were positively correlated $(r=0 \cdot 80)$. Mean spirometric values, six minute walking distance, the Karnofsky performance index, and breathlessness and wellbeing scores also improved significantly. Patients with main bronchial obstruction who had had no radiotherapy showed the most striking improvements. It is concluded that the removal of intraluminal tumour from the bronchial tree leads to matched improvements in ventilation and perfusion in most patients and that this is associated with valuable improvement in symptoms.
\end{abstract}

During the last eight years treatment with the neodymium YAG laser has become established as an important palliative treatment in patients with advanced lung cancer. ${ }^{1-3}$ The thermal action of this laser provides a convenient method of resecting intraluminal tumour from the upper airways and there is general agreement that it provides effective relief from breathlessness. Treatment is often dramatically effective in patients with tumours obstructing the trachea ${ }^{45}$ and main carina, but provides less striking clinical improvement in patients with more peripheral obstruction. ${ }^{3}$

The value of treating patients with tracheal and carinal tumours, who are at risk of asphyxiation, is not open to question but in patients with more peripheral obstruction evaluation of the physiological benefits of treatment is important. It is well known that perfusion to a lung affected by bronchogenic carcinoma may be considerably impaired ${ }^{6}$ and there is evidence in some patients to suggest that this is caused by tumour compressing or distorting the pulmonary vessels. ${ }^{7}$ Removal of the intraluminal component of a tumour from the airway might therefore improve ventilation but have no effect on perfusion, with the result that laser treatment might merely increase the physiological dead space within the lung.

We have examined changes in ventilation and perfusion produced by laser treatment of obstructing tumours by performing radionuclide lung scanning before and after treatment in a series of 28 consecutive patients.

\section{Methods}

PATIENTS

Patients with inoperable tumours were assessed initially by fibreoptic bronchoscopy. They were judged to be suitable for laser treatment if the airway was obstructed by predominantly intraluminal tumour, and they were recruited into the study if the tumour was causing unilateral obstruction within the bronchial tree.

We studied 28 patients (17 male and 11 female). The average age was 65 with a range of 43-80 years. Tissue was obtained for histological examination in all cases, with the following results: squamous cell carcinoma (22 patients), large cell carcinoma (2), adenocarcinoma (1), carcinoid tumour (2), and metastatic clear cell adenocarcinoma (1). The two patients with carcinoid tumours were judged to have inoperable disease as both had evidence of secondary disease affecting lymph nodes.

The obstruction was at the level of a main bronchus in 21 patients, the right intermediate bronchus in six, and the right lower lobe in one. Because of the small numbers, results from patients with obstruction of intermediate and lobar bronchi have been grouped together for subsequent analyses.

Thirteen patients had been treated previously with radiotherapy. Two patients had received a combination of radiotherapy and chemotherapy and one had received radiotherapy after surgery. The remaining 12 patients had not received any previous treatment. The patients could therefore be divided into two groups: 16 whose previous treatment included radiotherapy and 12 who had not received any previous treatment. The mean

\footnotetext{
Address for reprint requests: Dr P J M George, London Chest Hospital, London E2 9JX.

Accepted 30 November 1989

Anaesthetics,

Radioisotope

Scanning
} 
(SD) interval between the time of diagnosis and the first laser treatment was 20 (20) months in the radiotherapy group and 4 (7) months in the untreated group; this difference was significant ( $\mathrm{p}<0.05$, unpaired $t$ test).

\section{LASER TREATMENT}

All patients were treated with a neodymium YAG laser (Fiberlase 100, Pilkington Medical Systems) under general anaesthesia, a combination of flexible and rigid bronchoscopes being used. Full details of this method have been described. ${ }^{8}$ All treatments were performed by the same bronchoscopist (PJMG).

\section{RADIONUCLIDE LUNG SCANS}

Ventilation was assessed by the use of krypton-81m gas and perfusion with human albumin macroaggregates labelled with technetium-99m. ${ }^{9}$ Scanning was performed immediately before and either two or four days after laser treatment, depending on the availability of the parent isotope, rubidium81. Anterior and posterior views were obtained and the number of counts in each lung was averaged by taking the geometric mean from these two views. The geometric mean was used in preference to the arithmetic mean as it provides a correction for depth and therefore gives a more accurate estimate of whole lung counts.

Ventilation and perfusion were quantified by expressing the mean number of counts in the treated lung as a percentage of the sum of the counts from both lungs to produce a fractional score as follows:

\section{Fractional score $=$ mean counts from treated lung $\times 100$.} mean counts from both lungs

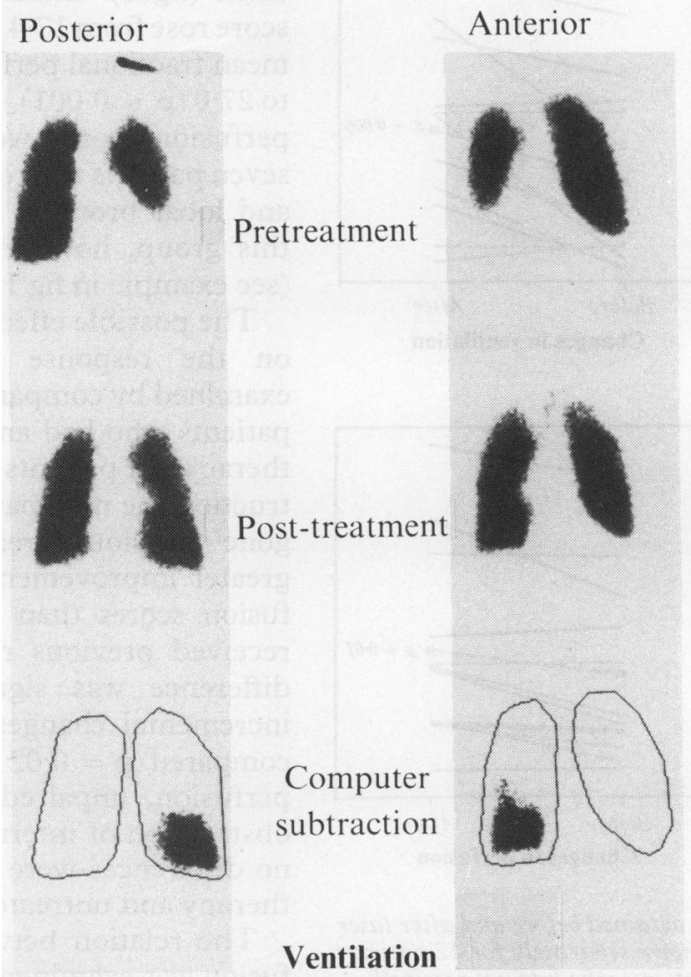

Data were acquired by the use of a dedicated computer during imaging and were analysed to produce subtraction images derived from scans before and after treatment. The purpose of the computer subtraction was to show the areas of change in the treated lung; an example is shown in figure 1 .

\section{ASSESSMENTS OF THE CLINICAL RESPONSE TO} TREATMENT

All patients were assessed immediately before and either two or four days after laser treatment (on the same day as the radionuclide lung scanning).

Mechanical lung function Peak expiratory flow (PEF) and spirometric indices were measured with a flow volume recorder (Floop System OD 2001). Measurements were corrected to BTPS.

Performance and effort tolerance Functional performance was assessed by using the Karnofsky performance index. ${ }^{10}$ Effort tolerance was assessed by measuring the distance walked in six minutes. " All walks were performed in an enclosed hospital corridor of 50 metres under the supervision of the same doctor (PJMG), who provided regular time checks and encouragement as necessary. Two practice walks were performed before the distance was recorded to minimise the effects of training and learning.

Arterial blood gases Before and after treatment samples of arterial blood were obtained for blood gas analysis in 15 patients. All samples were obtained from the radial artery with the patient at rest and breathing room air.

Symptom scores Breathlessness and wellbeing were quantified by means of $10 \mathrm{~cm}$ linear analogue scales. ${ }^{12}$ The ends of the scales

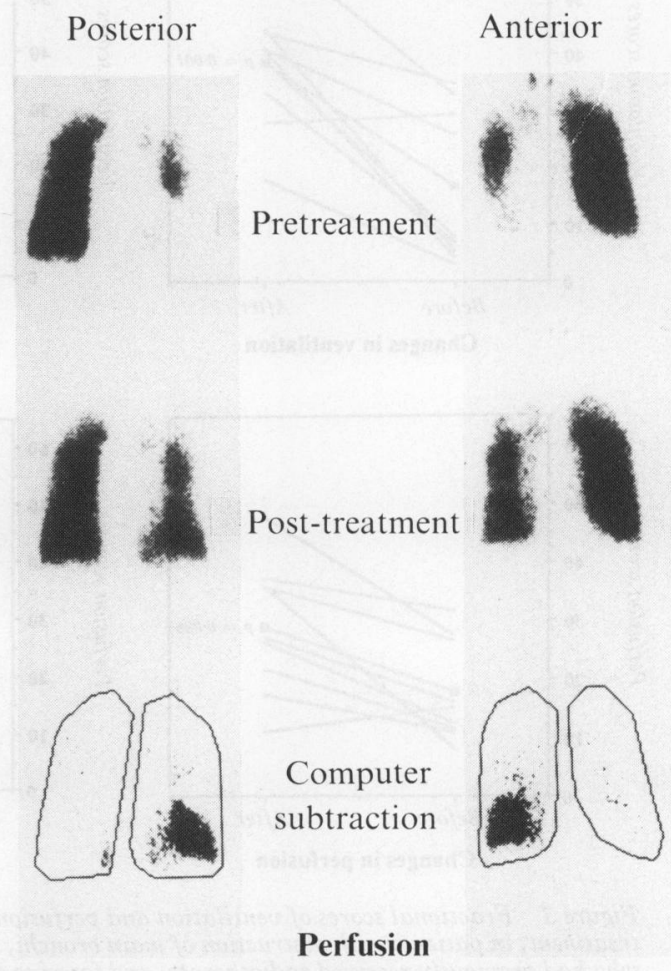

Figure 1 Radionuclide ventilation and perfusion scans immediately before and four days after laser treatment in a patient with a tumour (squamous cell carcinoma) obstructing the right intermediate bronchus. Regional changes in the treated lung have been identified by computer subtraction, in which the pretreatment image has been subtracted from the post-treatment image. A matched improvement in ventilation and perfusion is seen at the site that was treated. 
Main bronchial obstruction $(n=21)$

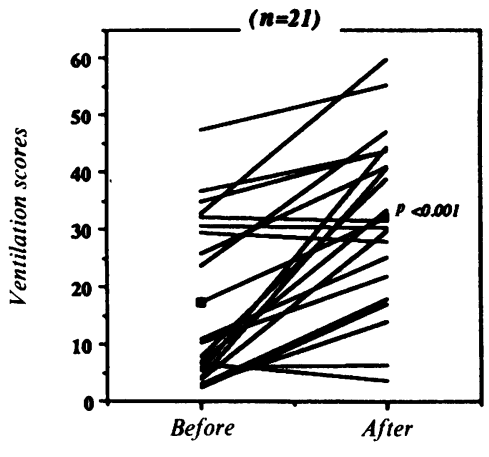

Changes in ventilation

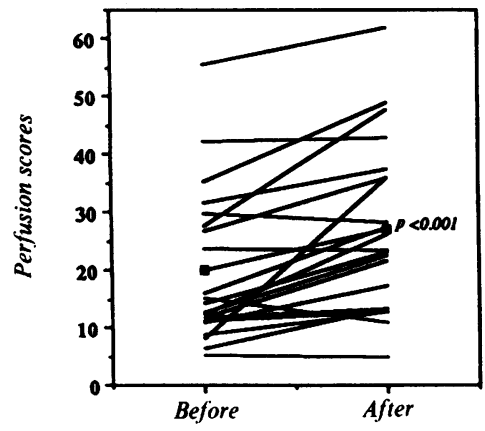

Changes in perfusion
Int/Lobar bronchial obstruction $(n=7)$
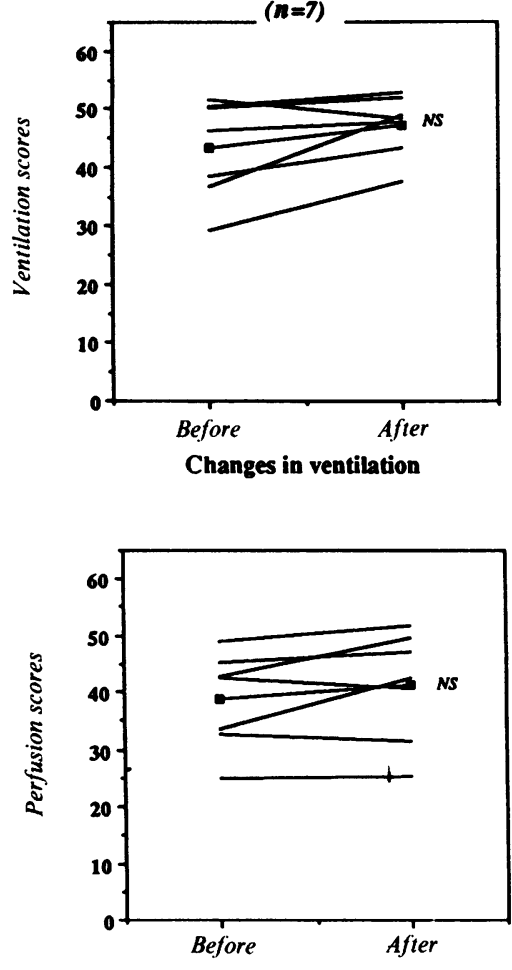

Changes in perfusion

Figure 2 Fractional scores of ventilation and perfusion, obtained before and after laser treatment, shown separately according to the site of endobronchial obstruction. Mean pretreatment and post-treatment values (with levels of significance) are shown by solid squares. Patients with obstruction of main bronchi tended to have the lowest ventilation and perfusion scores before treatment, but showed the greatest improvements after treatment. Int-intermediate.

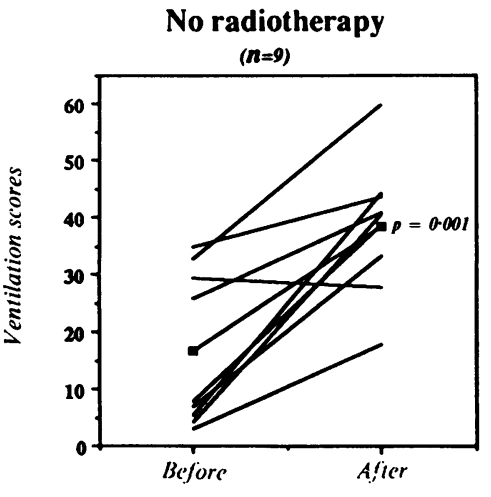

Changes in ventilation

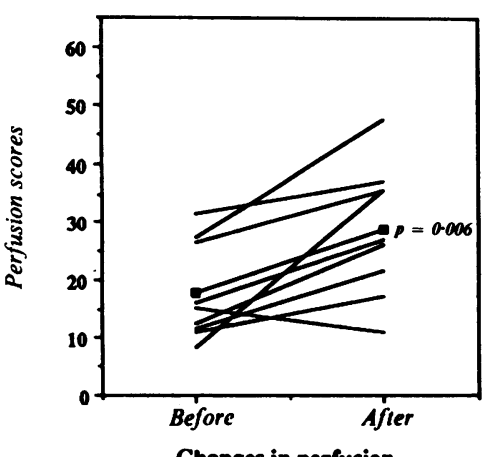

Changes in perfusion
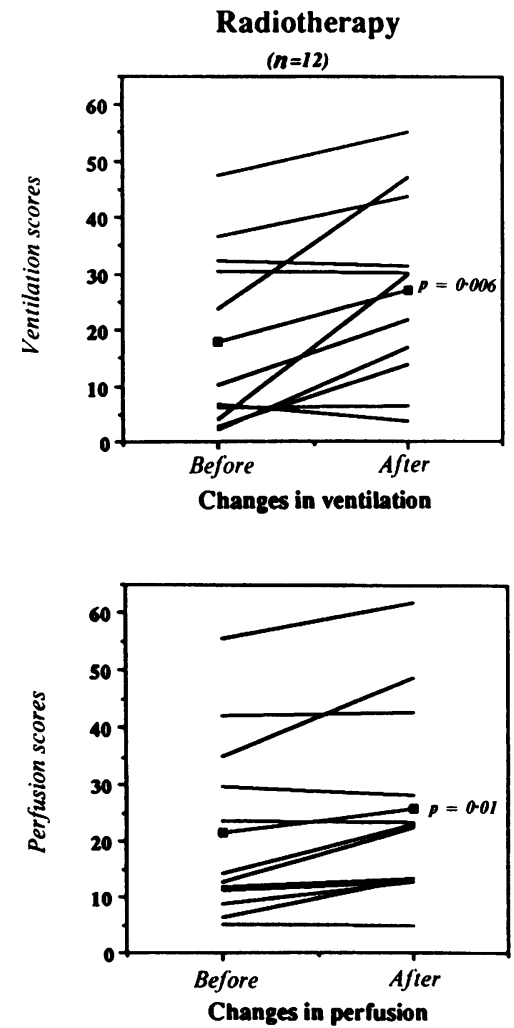

Figure 3 Fractional scores of ventilation and perfusion, obtained before and after laser treatment, in patients with obstruction of main bronchi, shown separately for 12 patients who had previously received radiotherapy and for nine patients who had not received radiotherapy. Mean pretreatment and post-treatment values (with levels of significance) are shown by solid squares. The mean incremental increases in ventilation and perfusion scores were significantly greater in patients who had not received radiotherapy. were marked "very, very breathless" and "not at all breathless" for breathlessness, and "very, very ill" and "very, very well" for wellbeing. The patients indicated with a mark where their present state fell between these two extremes, the worst possible score being $0 \mathrm{~mm}$ and the best possible score being $100 \mathrm{~mm}$. In addition, breathlessness was quantified by using the MRC questionnaire. ${ }^{13}$

\section{STATISTICAL METHODS}

Changes in indices of lung function, six minute walking distance, and fractional scores of ventilation and perfusion observed after laser treatment were evaluated by paired Student's $t$ tests. All other pretreatment and post-treatment data were compared by the Wilcoxon matched pairs signed rank test. Correlations between incremental changes in ventilation and perfusion scores were assessed by the method of least squares. Data from different groups of patients were compared by unpaired Student's $t$ tests.

\section{Results}

\section{RADIONUCLIDE LUNG SCANS}

Ventilation and perfusion scores improved in 23 patients $(82 \%)$. In all cases computer subtractions confirmed that the greatest improvements in ventilation and perfusion were in the treated areas. The mean ventilation score rose from 23.8 to 35.8 ( $p<0.001$ ), and the mean perfusion score rose from $24 \cdot 6$ to 30.6 $(\mathrm{p}<0.001)$.

Patients with tumours causing obstruction in main bronchi generally had the lowest ventilation and perfusion scores before treatment, but showed the greatest improvements after treatment (fig 2): the mean fractional ventilation score rose from 17.4 to $32.1(p<0.001)$ and the mean fractional perfusion score rose from $19 \cdot 1$ to 27.0 ( $p<0.001$ ). Changes in ventilation and perfusion scores were not significant in the seven patients with obstruction of intermediate and lobar bronchi; individual patients within this group, however, undoubtedly improved (see example in fig 1).

The possible effect of previous radiotherapy on the response to laser treatment was examined by comparing the results obtained in patients who had and had not received radiotherapy. In patients with main bronchial obstruction the nine patients who had not undergone previous treatment tended to show greater improvements in ventilation and perfusion scores than the 12 patients who had received previous radiotherapy (fig 3 ). This difference was significant when the mean incremental changes in the two groups were compared ( $p=0.02$ for ventilation and 0.04 for perfusion, unpaired $t$ test). In patients with obstruction of intermediate and lobar bronchi no differences were found between the radiotherapy and untreated groups.

The relation between ventilation and perfusion was examined by plotting the incremental changes in fractional ventilation scores against the incremental changes in fractional perfusion scores (fig 4). These were positively 


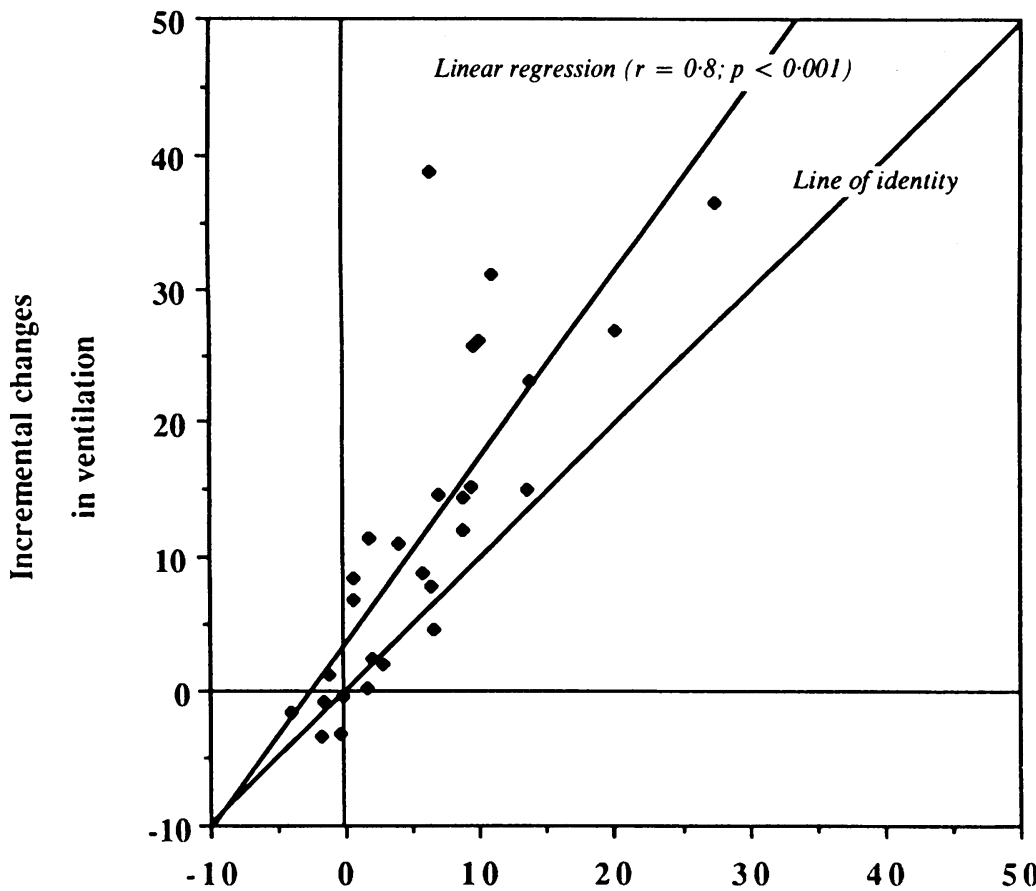

Incremental changes in perfusion

Figure 4 Incremental changes in ventilation scores (vertical axis) plotted against incremental changes in perfusion scores (horizontal axis) for the whole group of 28 patients. These changes were positively correlated $(r=0.80 ; p<0.001)$. Most of the plots lie above the line of identity as ventilation scores tended to increase more than perfusion scores. tumour site and previous radiotherapy on the response to treatment. Significant improvements in all indices were seen in the 21 patients with obstruction of main bronchi, but not in the seven patients with more peripheral obstruction. In patients with obstruction of main bronchi, the most impressive responses were again seen in patients who had not received radiotherapy. The patterns of change thus resembled those shown by radionuclide scanning.

Samples of arterial blood were obtained before and after laser treatment in 15 patients with main bronchial obstruction. The results were not examined for the possible effects of radiotherapy because of the small numbers. The mean (SD) arterial oxygen tension rose from $10 \cdot 1(2 \cdot 0)$ to $11 \cdot 1(1 \cdot 8) \mathrm{kPa}$; this increase did not, however, quite attain significance $(p=$ $0 \cdot 1$ ). There was no change in the mean pretreatment and post-treatment carbon dioxide tensions $(4 \cdot 1(1 \cdot 1)$ and $4 \cdot 2(0 \cdot 5) \mathrm{kPa})$.

\section{Discussion}

${ }^{81 \mathrm{~m}} \mathrm{Kr}$ ventilation and ${ }^{99 \mathrm{~m}} \mathrm{~T}$ perfusion scans provide an image of the relative distribution of ventilation and perfusion in the lung during physiological tidal breathing. ${ }^{9}$ Although the technique cannot provide absolute measurements of ventilation and perfusion, serial scans are thought to provide a reliable index of change. ${ }^{14}$ Our results thus provide evidence that laser treatment leads to improved ventilation and perfusion in the affected lung in patients with obstruction of the main bronchus. The effect of treatment in patients with more peripheral obstruction is more difficult to assess in view of the small number of patients studied; although significant improvements were not seen in the whole group, individual patients undoubtedly improved (fig 1).

Although ventilation scores tended to imanalysed to examine the possible effects of

Table 1 Mean (SD) peak expiratory flow and spirometric values before $(B)$ and after $(A)$ laser treatment

\begin{tabular}{|c|c|c|c|c|c|c|}
\hline & \multicolumn{2}{|c|}{$P E F(l / \min )$} & \multicolumn{2}{|c|}{$F E V_{1}(l)$} & \multicolumn{2}{|c|}{$F V C(l)$} \\
\hline & $B$ & $A$ & $B$ & $A$ & $\boldsymbol{B}$ & $A$ \\
\hline \multicolumn{7}{|l|}{ All patients } \\
\hline $\begin{array}{l}\text { All sites }(\mathrm{n}=28) \\
\text { Main bronchus } \\
\quad(\mathrm{n}=21) \\
\text { Intermediate or lobar } \\
\text { bronchi }(\mathrm{n}=7)\end{array}$ & $\begin{array}{l}259 \\
(148) \\
240 \\
(128) \\
309 \\
(194)\end{array}$ & $\begin{array}{l}280 \\
(105) \\
271^{\star} \\
(103) \\
306 \\
(114)\end{array}$ & $\begin{array}{l}1 \cdot 35 \\
(0 \cdot 35) \\
1 \cdot 30 \\
(0 \cdot 34) \\
1 \cdot 47 \\
(0 \cdot 35)\end{array}$ & $\begin{array}{l}1.57^{\star \star} \\
(0.45) \\
1.55^{\star} \\
(0.50) \\
1.61 \\
(0.35)\end{array}$ & $\begin{array}{l}2 \cdot 26 \\
(0 \cdot 70) \\
2 \cdot 16 \\
(0 \cdot 71) \\
2 \cdot 54 \\
(0 \cdot 66)\end{array}$ & $\begin{array}{l}2 \cdot 65^{\star \star \star \star} \\
(0 \cdot 70) \\
2 \cdot 60^{\star \star \star \star} \\
(0 \cdot 76) \\
2 \cdot 76 \\
(0 \cdot 57)\end{array}$ \\
\hline \multicolumn{7}{|c|}{ Patients treated previously with radiotherapy } \\
\hline $\begin{array}{l}\text { All sites }(n=16) \\
\text { Main bronchus } \\
\quad(n=12)\end{array}$ & $\begin{array}{l}236 \\
(136) \\
254 \\
(156)\end{array}$ & $\begin{array}{l}268 \\
(105) \\
272 \\
(119)\end{array}$ & $\begin{array}{l}1 \cdot 35 \\
(0 \cdot 33) \\
1 \cdot 36 \\
(0 \cdot 36)\end{array}$ & $\begin{array}{l}1 \cdot 40 \\
(0 \cdot 43) \\
1 \cdot 36 \\
(0 \cdot 48)\end{array}$ & $\begin{array}{l}2 \cdot 25 \\
(0 \cdot 61) \\
2 \cdot 22 \\
(0 \cdot 64)\end{array}$ & $\begin{array}{l}2 \cdot 53^{\star} \\
(0.60) \\
2.45 \\
(0.61) \\
(0.1)\end{array}$ \\
\hline $\begin{array}{l}\text { Intermediate or lobar } \\
\text { bronchi }(n=4)\end{array}$ & $\begin{array}{l}193 \\
(64)\end{array}$ & $\begin{array}{l}261^{\star} \\
(70)\end{array}$ & $\begin{array}{l}1 \cdot 32 \\
(0 \cdot 29)\end{array}$ & $\begin{array}{l}1 \cdot 49 \\
(0 \cdot 29)\end{array}$ & $\begin{array}{l}2 \cdot 32 \\
(0 \cdot 61)\end{array}$ & $\begin{array}{l}p>0.05) \\
2.75 \\
(0.58)\end{array}$ \\
\hline \multicolumn{7}{|c|}{ Patients not treated previously } \\
\hline $\begin{array}{l}\text { All sites }(\mathrm{n}=12) \\
\text { Main bronchus } \\
(\mathrm{n}=9) \\
\text { Intermediate or lobar } \\
\text { bronchi }(\mathrm{n}=3)\end{array}$ & $\begin{array}{l}285 \\
(162) \\
225 \\
(96) \\
464 \\
(209)\end{array}$ & $\begin{array}{l}294 \\
(107) \\
270 \\
(87) \\
366 \\
(151)\end{array}$ & $\begin{array}{l}1.35 \\
(0.38) \\
1.23 \\
(0 \cdot 33) \\
1.67 \\
(0.37)\end{array}$ & $\begin{array}{l}1 \cdot 78^{\star \star} \\
(0 \cdot 42) \\
1 \cdot 78^{\star \star \star} \\
(0 \cdot 44) \\
1 \cdot 77 \\
(0 \cdot 43)\end{array}$ & $\begin{array}{l}2 \cdot 23 \\
(0 \cdot 84) \\
2 \cdot 08 \\
(0 \cdot 83) \\
2 \cdot 83 \\
(0 \cdot 71)\end{array}$ & $\begin{array}{l}2 \cdot 79 \star \star \\
(0 \cdot 82) \\
2 \cdot 80 \star \star \star \\
(0 \cdot 91) \\
2 \cdot 77 \\
(0 \cdot 69)\end{array}$ \\
\hline
\end{tabular}

${ }^{\star} \mathrm{p}<0.05 ;{ }^{\star \star} \mathrm{p}<0.01 ;{ }^{\star \star \star} \mathrm{p}<0.005 ;{ }^{\star \star \star \star} \mathrm{p}<0.001$, in the comparison of pretreatment and post-treatment values (paired Student's $t$ test).

$\mathrm{PEF}$ - peak expiratory flow; $\mathrm{FEV}_{1}$-forced peak capacity in one second; FVC-forced vital capacity. 
Table 2 Mean (SD) scores of breathlessness, wellbeing, and performance and six minute walking distances before (B) and after $(A)$ laser treatment

\begin{tabular}{|c|c|c|c|c|c|c|c|c|c|c|}
\hline & \multicolumn{4}{|c|}{ Breathlessness } & \multirow{2}{*}{\multicolumn{2}{|c|}{$\begin{array}{l}\text { Wellbeing } \\
V A S: \\
(0-100)\end{array}$}} & \multirow{2}{*}{\multicolumn{2}{|c|}{$\begin{array}{l}\text { Karmofsky } \\
\text { performance } \\
\text { index }(0-100)\end{array}$}} & \multirow{2}{*}{\multicolumn{2}{|c|}{$\begin{array}{l}\text { Six minute } \\
\text { walk }(m)\end{array}$}} \\
\hline & \multicolumn{2}{|c|}{$(V A S: 0-100)$} & \multicolumn{2}{|c|}{$(M R C: 1-5)$} & & & & & & \\
\hline & $B$ & $A$ & $B$ & $A$ & $B$ & $A$ & $B$ & $A$ & $\boldsymbol{B}$ & $A$ \\
\hline \multicolumn{11}{|l|}{ All patients } \\
\hline $\begin{array}{l}\text { All sites }(\mathrm{n}=28) \\
\text { Main bronchus } \\
(\mathrm{n}=21) \\
\text { Intermediate or lobar } \\
\text { bronchi }(\mathrm{n}=7)\end{array}$ & $\begin{array}{l}48 \\
(23) \\
44 \\
(22) \\
59 \\
(22)\end{array}$ & $\begin{array}{l}67^{\star \star \star \star} \\
(14) \\
64^{\star \star \star \star} \\
(15) \\
74 \\
(10)\end{array}$ & $\begin{array}{l}3 \cdot 5 \\
(1 \cdot 2) \\
3 \cdot 6 \\
(1 \cdot 3) \\
3 \cdot 3 \\
(1 \cdot 3)\end{array}$ & $\begin{array}{l}2 \cdot 7^{\star \star \star} \\
(1 \cdot 4) \\
2 \cdot 6^{\star \star \star \star} \\
(1 \cdot 5) \\
3 \cdot 0 \\
(1 \cdot 2)\end{array}$ & $\begin{array}{l}57 \\
(21) \\
51 \\
(20) \\
75 \\
(11)\end{array}$ & $\begin{array}{l}71^{\star \star \star} \\
(17) \\
69 \star \star \star \\
(18) \\
79 \\
(11)\end{array}$ & $\begin{array}{l}67 \\
(19) \\
64 \\
(21) \\
76 \\
(11)\end{array}$ & $\begin{array}{l}78^{\star \star \star \star} \\
(13) \\
76^{\star \star \star} \\
(13) \\
84^{\star} \\
(11)\end{array}$ & $\begin{array}{l}443 \\
(188) \\
412 \\
(185) \\
571 \\
(159)\end{array}$ & $\begin{array}{l}512^{\star \star \star} \\
(164) \\
492^{\star \star} \\
(160) \\
598 \\
(176)\end{array}$ \\
\hline \multicolumn{11}{|c|}{ Patients treated previously with radiotherapy } \\
\hline All sites $(n=16)$ & $\begin{array}{l}46 \\
(22)\end{array}$ & $\begin{array}{l}67^{\star \star \star} \\
(13)\end{array}$ & $\begin{array}{l}3.9 \\
(1 \cdot 3)\end{array}$ & $\begin{array}{l}3 \cdot 2^{\star} \\
(1 \cdot 4)\end{array}$ & $\begin{array}{l}56 \\
(24)\end{array}$ & $\begin{array}{l}70^{\star} \\
(19)\end{array}$ & $\begin{array}{l}66 \\
(16)\end{array}$ & $\begin{array}{l}74^{\star} \\
(12)\end{array}$ & $\begin{array}{l}389 \\
(216)\end{array}$ & \multirow{3}{*}{$\begin{array}{l}458 \\
(178) \\
(0.1> \\
p>0.05) \\
455 \\
(195) \\
(0.1> \\
p>0.05) \\
475 \\
(71)\end{array}$} \\
\hline $\begin{array}{l}\text { Main bronchus } \\
\quad(\mathrm{n}=12)\end{array}$ & $\begin{array}{l}44 \\
(24)\end{array}$ & $\begin{array}{l}65^{\star} \\
(14)\end{array}$ & $\begin{array}{l}4 \cdot 0 \\
(1 \cdot 3)\end{array}$ & $\begin{array}{l}3 \cdot 2 \\
(1.5) \\
(0.1> \\
p>0.05)\end{array}$ & $\begin{array}{l}47 \\
(24)\end{array}$ & $\begin{array}{l}67^{\star} \\
(14)\end{array}$ & $\begin{array}{l}64 \\
(16)\end{array}$ & $\begin{array}{l}73 \\
(13)\end{array}$ & $\begin{array}{l}375 \\
(236)\end{array}$ & \\
\hline $\begin{array}{l}\text { Intermediate or lobar } \\
\text { bronchi }(n=4)\end{array}$ & $\begin{array}{l}53 \\
(18)\end{array}$ & $\begin{array}{l}74 \\
(10)\end{array}$ & $\begin{array}{l}3 \cdot 8 \\
(1 \cdot 5)\end{array}$ & $\begin{array}{l}3 \cdot 3 \\
(1 \cdot 3)\end{array}$ & $\begin{array}{l}77 \\
(10)\end{array}$ & $\begin{array}{l}77 \\
(11)\end{array}$ & $\begin{array}{l}73 \\
(13)\end{array}$ & $\begin{array}{l}78 \\
(10)\end{array}$ & $\begin{array}{l}463 \\
(18)\end{array}$ & \\
\hline \multicolumn{11}{|c|}{ Patients not treated previously } \\
\hline $\begin{array}{l}\text { All sites }(\mathrm{n}=12) \\
\text { Main bronchus } \\
(\mathrm{n}=9) \\
\text { Intermediate or lobar } \\
\text { bronchi }(\mathrm{n}=3)\end{array}$ & $\begin{array}{l}50 \\
(24) \\
44 \\
(21) \\
67 \\
(28)\end{array}$ & $\begin{array}{l}66^{\star \star} \\
(16) \\
63^{\star \star \star} \\
(17) \\
74 \\
(12)\end{array}$ & $\begin{array}{l}3 \cdot 1 \\
(1 \cdot 0) \\
3 \cdot 2 \\
(1 \cdot 1) \\
2 \cdot 7 \\
(0 \cdot 6)\end{array}$ & $\begin{array}{l}2 \cdot 2^{\star} \\
(1 \cdot 1) \\
2 \cdot 0^{\star \star \star} \\
(1 \cdot 1) \\
2 \cdot 7 \\
(1 \cdot 2)\end{array}$ & $\begin{array}{l}59 \\
(17) \\
54 \\
(16) \\
72 \\
(14)\end{array}$ & $\begin{array}{l}73^{\star} \\
(15) \\
70^{\star} \\
(15) \\
82 \\
(14)\end{array}$ & $\begin{array}{l}68 \\
(24) \\
63 \\
(26) \\
82 \\
(8)\end{array}$ & $\begin{array}{l}83^{\star \star} \\
(14) \\
79^{\star} \\
(14) \\
93 \\
(6)\end{array}$ & $\begin{array}{l}513 \\
(118) \\
465 \\
(46) \\
680 \\
(170)\end{array}$ & $\begin{array}{l}583^{\star \star} \\
(117) \\
545^{\star} \\
(75) \\
720 \\
(170)\end{array}$ \\
\hline
\end{tabular}

${ }^{\star} \mathrm{p}<0.05 ;{ }^{\star} \mathrm{p}<0.01 ; \star \star \star \mathrm{p}<0.005 ; \star \star \star \star \mathrm{p}<0.001$, in the comparison of pretreatment and post-treatment values (Wilcoxon matched pairs signed rank test for all data except the results of the six minute walk, which were assessed by the paired Student's $t$ test).

VAS-visual analogue scale; MRC-Medical Research Council. ${ }^{13}$

prove more than perfusion scores, incrementa changes in individual patients were positively correlated (fig 4). This suggests that laser treatment should lead to an overall improvement in gas exchange rather than merely increase the physiological dead space within the lung. The changes in arterial blood gases observed after treatment in patients with main bronchial obstruction, though not attaining statistical significance, suggest a reduction in the proportion of lung units with unfavourable ventilation: perfusion ratios.

The results obtained with radionuclide lung scans were consistent with independently obtained assessments. The groups showing the most striking improvements in lung function (table 1) and performance and symptom scores (table 2) also showed the most striking improvements in ventilation and perfusion. Symptomatic and clinical improvement thus appears to reflect a genuine physiological gain rather than a simple placebo effect of the laser.

Gilmartin et $a l^{15}$ have recently reported changes in perfusion in patients undergoing treatment with a carbon dioxide laser. Improvements in perfusion were noted in seven out of 13 patients 10 days after treatment; the changes were relatively modest, however, and not significant. The patients in that study and the method of assessing perfusion were similar to ours; but the carbon dioxide laser may represent an important difference. The beam of this laser cannot be transmitted in a conventional optical fibre and so a rigid delivery system must be used. Access to peripherally situated tumours may therefore not be as good as with the neodymium YAG laser, with the result that the airway may not be so thoroughly cleared.

In the study by Gilmartin et $a l^{15}$ indices of lung function and breathlessness tended to improve between the first and the tenth postoperative day. Resolution of exudate and oedema at the site of treatment and recovery from the anaesthetic were thought to account for this gradual improvement. In the present cudy postoperative assessments were performed on either the second or the fourth day, when these effects may still be operating. Possibly therefore our results have underestimated the improvement that was obtained with the neodymium YAG laser.

Significant improvements in ventilation and perfusion have been observed in patients undergoing radiotherapy. ${ }^{14}$ The nature of the response was similar to that reported here; the action of radiotherapy on the lung, however, is likely to differ from that of the laser. The improvements in ventilation and perfusion obtained with radiotherapy were thought to result from shrinkage of the tumour, with consequent relief of infiltration or compression of airways and blood vessels, or both. ${ }^{14}$ Laser treatment, on the other hand, probably has little effect on the mechanical compression of blood vessels.

How then does laser treatment improve lung perfusion? It is well known that alveolar hypoxia leads to reflex regional pulmonary vasoconstriction. ${ }^{16}$ Studies in dogs have shown that obstruction of the bronchial tree with balloon catheters leads to large perfusion defects, and it has been suggested that endobronchial tumours produce similar effects 
through regional hypoxia. ${ }^{17}$ We may reasonably assume that laser treatment corrects alveolar hypoxia and that the improvement in perfusion is a physiological response to this change.

In addition to regional hypoxia, mechanisms such as tumour compression of blood vessels ${ }^{7}$ must account for some of the impairment in lung perfusion. Indeed, these other mechanisms may explain why the improvements in perfusion appeared to be smaller than those in ventilation after laser treatment. Nevertheless, this study shows that these various effects do not negate the value of removing intraluminal tumour from the bronchial tree in patients with advanced disease.

Although external radiotherapy has been shown to lead to improved ventilation and perfusion in the short term in patients with endobronchial tumours, ${ }^{14}$ it may have a deleterious longer term action as a result of the delayed effects of radiation induced lung damage. ${ }^{18}$ This may explain the relatively poor result that was seen in the 12 patients with main bronchial obstruction who had already undergone radiotherapy (fig 3). Possibly, however, these patients also had more advanced tumours than the untreated group and so the poor response could be due, in part, to the compressive effects of more extensive local tumour. Nevertheless, the improvements in ventilation and perfusion scores in the radiotherapy group were significant and were associated with improvements in lung function, performance, and symptom scores.

Despite its damaging effects, ${ }^{18}$ external radiotherapy remains standard palliative treatment for patients with non-small cell lung cancer. Less conventional methods of treatment, however, such as endoscopic laser resection and intraluminal radiotherapy, ${ }^{19} 20$ have important theoretical advantages. If they cause less damage to adjacent normal tissues, their use in preference to palliative external radiotherapy should be associated with superior lung function and quality of life. A trial comparing external radiotherapy with these local palliative techniques would now be of great interest.

Although endoscopic laser resection is a relatively safe treatment, it inevitably carries a risk in debilitated patients with advanced lung cancer. ${ }^{8}$ It is important therefore to define the patients who may be expected to benefit from treatment. We believe that the results presented in this paper testify to the value of treatment in patients with obstruction of main bronchi. Firm conclusions on the value of treatment in patients with more peripheral endobronchial obstruction, however, cannot yet be drawn and must await the study of a larger number of patients.

This work was generously supported by the North East Thames Regional Health Authority and Pilkington Medical Systems. We are also grateful to Drs P J Ell and M Buxton-Thomas for their helpful advice, and to Miss Sue Huggett for her technical assistance.

1 Toty L, Personne C, Colchen A, Vourc'h G. Bronchoscopic management of tracheal lesions using the neodymiumyttrium-aluminium-garnet laser. Thorax 1981;36:175-8.

2 Parr GVS, Unger M, Trout RG, Atkinson WG. One hundred neodymium-YAG laser ablations of obstructing tracheal neoplasms. Ann Thorac Surg 1984;38:374-9.

3 Hetzel MR, Nixon C, Edmonstone WM, et al. Laser therapy in 100 tracheobronchial tumours. Thorax 1985;40:341-5.

4 George PJM, Garrett CPO, Goldstraw P, Hetzel MR, Ramsay AD. Resuscitative laser photoresection of a tracheal tumour before elective surgery. Thorax 1986; 41:812-3.

5 George PJM, Garrett CPO, Hetzel MR. The role of the neodymium YAG laser in the management of tracheal tumours. Thorax 1987;42:440-4

6 Secker-Walker RH, Alderson PO, Wilhelm J, Hill RL, Markham J, Kinsie J. Ventilation-perfusion scanning in carcinoma of the bronchus. Chest 1974;65:660-3.

7 Garnett ES, Goddard BA, Fraser HS, Macleod WM. Lung perfusion patterns in carcinoma of bronchus. Br Med J 1968;ii:209-10.

8 George PJM, Garrett CPO, Nixon C, Hetzel MR, Nanson EM, Millard FJC. Laser treatment for tracheobronchial tumours: local or general anaesthesia? Thorax 1987;42: tumours:

9 Fazio F, Jones T. Assessment of regional ventilation by continuous inhalation of radioactive krypton-81m. $\mathrm{Br}$ Med J 1975;iii:673-6.

10 Karnofsky DA, Burchenal JH. The clinical evaluation of chemotherapeutic agents in cancer. In: MacLeod C, ed. Evaluation of chemotherapeutic agents. New York: Columbia University Press, 1948.

11 Butland RJA., Pang JA, Gross ER, Woodcock AA, Geddes DM. Two-, six-, and twelve-minute walking tests in respiratory disease. $\mathrm{Br} \mathrm{Med} J$ 1982;284:1607-8.

12 Aitken RCB. Measurement of feelings using visual analogue scales. Proc $R$ Soc Med 1969;62:989-93.

13 Medical Research Council. Questionnaire on respiratory symptoms. London: Medical Research Council, 1966.

14 Fazio F, Pratt TA, McKenzie CG, Steiner RE. Improvement in regional ventilation and perfusion after radiotherapy for unresectable carcinoma of the bronchus. $A J R$ 1979;133:191-200.

15 Gilmartin JJ, Veale D, Cooper BG, Keavey PM, Gibson GJ, Morritt GN. Effects of laser therapy on respiratory function in malignant narrowing of the central airway. Thorax 1987;42:578-82.

16 Hughes JMB. Lung gas tensions and active regulation of ventilation/perfusion ratios in health and disease. $\mathrm{Br} J \mathrm{Dis}$ Chest 1975;69:153-70.

17 Wagner HN, Lopez-Majano V, Tow DE, Langan JK. Radioisotope scanning of lungs in early diagnosis of bronchogenic carcinoma. Lancet 1965;i:344.

18 Gross NJ. Pulmonary effects of radiation therapy. Ann Intern Med 1977;86:81-92.

19 Macha HN, Koch K, Stadler M, Schumacher W, Krumhaar D. New technique for treating occlusive and stenosing tumours of the trachea and main bronchi: Endobronchial irradition by high dose iridium-192 combined with laser canalisation. Thorax 1987;42:511-5.

20 Schray MF, McDougall JC, Martinez A, Cortese DA, Brutinel WM. Management of malignant airway compromise with laser and low dose rate brachytherapy: The Mayo Clinic experience. Chest 1988;93:264-9. 